\title{
Green Technologies for Soil Remediation
}

\author{
Vimal Chandra Pandey ${ }^{1}\left[\right.$ Gordana Gajić $^{2}$
}

Received: 15 February 2022 / Accepted: 16 February 2022 / Published online: 19 February 2022

(c) The Author(s), under exclusive licence to Springer Science+Business Media, LLC, part of Springer Nature 2022

Soil is a precious and non-renewable resource. Soil pollution is continuing across the world in response to urbanization, industrialization, agriculture practice and population growth. As a result, soil has been contaminated with wide-ranging potentially harmful pollutants at rates that have significantly reduced its quality. Soil remediation and management are important issues worldwide to secure soil function. The role of Green technologies in soil remediation is vital and provides a wide range of benefits towards environmental sustainability. Soil quality is crucial to fulfil all the needs of human life and environmental health. Therefore, the restoration of contaminated land is essential for regaining biodiversity and ecosystems services and thereby achieving United Nations-Sustainable Development Goals (UN-SDGs) (www. sustainabledevelopment.un.org). These facts reveal the need to further develop research into soil remediation. Over the past decades to present, Green technology based soil remediation has developed significantly (Pandey 2021). Therefore, Green technologies have the potential to secure soil for the land remediation programs targeted during the United Nations Decade of Ecosystem Restoration (2021-2030). Taking into account the importance of the Green technologies for soil remediation towards nature sustainability, this special issue includes contributions that cover the cuttingedge research, outcomes and developments on these very important technologies.

This special issue reveals state-of-art studies on broad topics of ecological restoration, phytoremediation of metal(loid)s and organic compounds as well as the application of bacteria and arbuscular mycorrhizal fungi that assist

Vimal Chandra Pandey

vimalcpandey@gmail.com

1 Department of Environmental Science, Babasaheb Bhimrao Ambedkar University, Lucknow, Uttar Pradesh 226025, India

2 Department of Ecology, Institute for Biological Research "Sinisa Stankovic", National Institute of Republic of Serbia, University of Belgrade, Bulevar Despota Stefana 142, 11000 Belgrade, Serbia in phytoremediation of contaminated sites. Furthermore, this special issue hosts studies by other researchers working in remediation of wastewater by algae and oyster shells. The first section focuses on the role of litter decomposition in restoration of fly ash ecosystem, effects of biochar, compost, activated carbons and red mud on the plant growth on mine soil whereas some articles highlight the removal of $\mathrm{As}, \mathrm{Pb}$ and azo dye from contaminated soil by various plant species. This section also includes a paper related to weed management on soil microflora. The second section focuses on removal of toxic Mn concentration in wheat by arbuscular mycorrhiza, $\mathrm{Zn}$ removal by Pseudomonas aeruginosaHMR1, a thorough review about genetic engineering and novel Omics that enhance bioremediation, and metagenomics combined with stable isotope probe for the discovery of novel dehalogenases producing bacteria. Finally, the third section deals with green approaches that includes utilization of algae, such as Chlorella pyrenoidosa, Chlorella vulgaris, and Chlorococcum sp. in remediation of wastewater from As and textile industries. This section also provides extensive research on modified oyster waste shells as sorbent for $\mathrm{Pb}$ removal from wastewater.

The content of this Special Issue provides all significant aspects of Green technologies for mitigation of environmental contamination and cleanup of polluted soil/wastewater. The content covers advances in efficient soil/wastewater resources, sustainable remediation and management thus providing the scientific basis for ecosystem services, policy framework, regulatory agencies and stakeholders worldwide.

The Guest Editors would like to thank Dr. Erin Bennett, Editor-in-Chief of Bulletin of Environmental Contamination and Toxicology (BECT) and all editorial staff of BECT for their support and co-operation. We are grateful to all authors and reviewers for their contribution and efforts. 


\section{Reference}

Pandey VC (2021) Assisted phytoremediation. Elsevier, Amsterdam, p 419, ISBN 9780128228937
Publisher's Note Springer Nature remains neutral with regard to jurisdictional claims in published maps and institutional affiliations. 